\title{
Chyle Fistula after Neck Dissection for an Unusual Breast Cancer Recurrence
}

\author{
Ali Harlak Serdar Karahatay $^{\mathrm{b}} \quad$ Onder Onguru $^{\mathrm{c}} \quad$ Oner Mentes $^{\mathrm{a}} \quad$ Mustafa Gerek $^{\mathrm{b}} \quad$ Turgut Tufan $^{\mathrm{a}}$ \\ a Department of General Surgery, \\ ${ }^{b}$ Department of Otolaryngology, \\ c Department of Pathology, Gulhane Military Medical Academy Ankara, Turkey
}

\author{
Key Words \\ Chyle fistula - Breast cancer $\cdot$ Thyroid cancer
}

\section{Summary}

Background: Chyle fistula is one of the rare complications of neck dissections. Even though no consented algorithm for the management of this entity has been established yet, conservative treatment options including somatostatin analogues have been suggested as an adequate modality for low output fistulas. Case Report: Here we present a patient with a right-sided neck fistula which was resistant to conventional treatment, and was finally treated by surgery. The neck dissection was performed for a malignant right neck mass that was accepted as the lymph node metastasis of formerly treated papillary thyroid carcinoma. The pathology of the specimen revealed a contralateral neck metastasis of previously treated breast carcinoma. Conclusion: We assume that consecutive surgeries on axillary and neck lymph pathways resulted in such a complicated and exceptional case.

\section{Introduction}

Chyle fistula (CF) is a rare but potentially devastating and morbid complication after neck dissection. CF occurs in $1-2.5 \%$ of dissections performed at the base of the neck [1]. Although the majority of CF is reported on the left side, the

\author{
Schlüsselwörter \\ Chylusfistel · Brustkrebs · Schilddrüsenkrebs
}

\section{Zusammenfassung}

Background: Chylusfisteln sind eine seltene Komplikation der radikalen Ausräumung der Halslymphknoten (neck dissection). Während bisher kein allgemein akzeptierter Algorithmus für das Management dieser Entität besteht, gibt es konservative Therapievorschläge (einschließlich Somatostatin-Analoga), die als adäquate Behandlungsmodalität für wenig Flüssigkeit produzierende Fisteln gewertet werden. Fallbericht: Wir stellen eine Patientin mit einer rechtsseitigen Halsfistel vor, die nach Versagen der konventionellen Therapie chirurgisch behandelt wurde. Die Entfernung der Halslymphknoten war auf Grund eines malignen Tumors in der rechten Halshälfte durchgeführt worden, welcher als Lymphknotenmetastase eines zuvor behandelten papillären Schilddrüsenkarzinoms angesehen worden war. Die pathologische Untersuchung der Proben ergab jedoch eine kontralaterale Halsmetastase eines zuvor behandelten Mammakarzinoms. Schlussfolgerung: Wir meinen, dass aufeinanderfolgende Eingriffe an den Lymphbahnen der Axilla und des Halses zu einem solchen komplizierten und außergewöhnlichen Fall geführt haben.

right thoracic duct can also be injured with an incidence of $8-25 \%$ of all CF [2]. Treatment options depend on duration and daily volume of chyle leakage.

We report the case of a patient with a history of both right thyroid papillary carcinoma and left breast invasive ductal carcinoma, who presented with a progressive, supraclavicular

\section{KARGER}

Fax +497614520714

Information@Karger.de

www.karger.com (c) 2008 S. Karger GmbH, Freiburg

Accessible online at:

www.karger.com/brc
Ali Harlak, M.D.

Department of General Surgery

Gulhane Military Medical Academy

Etlik, Ankara, Turkey

Tel. +90 0312 30450-20, Fax -00

aharlak@yahoo.com 
Fig. 1. Histopathological examination shows metastatic infiltrative ductal carcinoma of the breast to the lymph node $(\mathrm{H}$ and $\mathrm{E} \times 100)$.

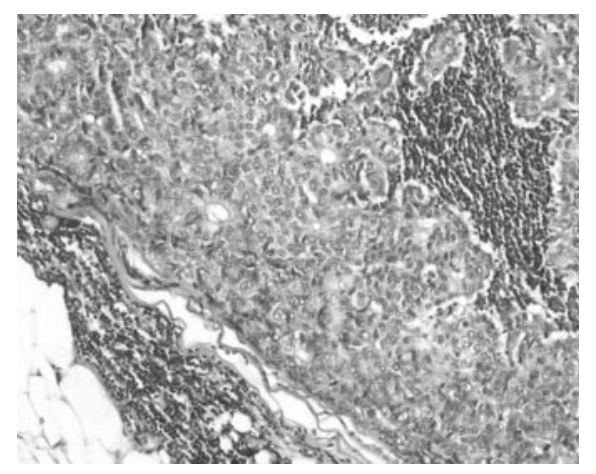

mass on the right side of the neck. Lack of proper histo-pathological diagnosis before treatment forced the surgeons to perform a neck dissection which was complicated by a postoperative CF. Histopathological examination of the specimen revealed metastasis of invasive ductal carcinoma. Finding the right breast normal, this metastasis was considered to be a recurrence of previously treated contralateral breast carcinoma, which is a rare entity. The CF was resistant to conservative treatment and somatostatin analogue administration even though the output was under $500 \mathrm{ml}$ daily. This situation contradicts the literature $[3,4]$. Having observed these 2 rare entities in 1 patient inspired us to present the case.

\section{Case Report}

The patient was a 41-year-old woman who had undergone total thyroidectomy for right lobe thyroid papillary carcinoma 7 years before. She had also had a left modified radical mastectomy for invasive ductal carcinoma of the left breast 4 years before. After an uneventful follow-up period, she had recently noticed a mass in her right supraclavicular region. Computerized tomography revealed lymph nodes in the right neck that were suspicious of metastasis. Consecutive fine needle aspiration biopsies of the mass confirmed a malignancy, however, an exact histopathological diagnosis was not achieved. Taking the high risk of regional recurrence of thyroid papillary carcinoma and extremely rare occurrence of contralateral neck metastasis of breast carcinoma into account, a right modified neck dissection was planned for both diagnosis and treatment. Unfortunately, this decision precluded the surgical team from carrying out further differential diagnostic procedures. During the neck dissection, no chyle drainage was observed in the surgical field. Routine pathological examination of the specimen confirmed 5 metastatic lymph nodes at the posterior triangle (fig. 1). Estrogen receptor expression was detected by immunohistochemistry in neoplastic cells. TTF-1 and galektin-3 expression were negative. The right breast was normal so that the metastatic lymph nodes were considered as recurrences of previous, contralateral breast cancer.

On the second postoperative day, approximately $300 \mathrm{ml}$ of gray-white, turbid fluid were drained off. Biochemical analysis of the fluid confirmed the presence of white blood cells at $1.63 \times 10^{3} / \mu$ l, consisting of lymphocytes (98\%), with total protein of $3.8 \mathrm{gr} / \mathrm{dl}$. Triglyceride was $1,012 \mathrm{mg} / \mathrm{dl}$. The appearance of the fluid and biochemical results concluded CF. Closedwound drainage, local pressure dressing, and low fat nutritional support were used as a first-step treatment for the first 2 days. On the 4th postoperative day, chyle drainage was still more than $300 \mathrm{ml}$. The somatostatin analogue octreotide (Sandostatin ${ }^{\circledR}$, Novartis Pharma AG, Basel, Switzerland), was added to the treatment at a dose of $0.1 \mathrm{mg}$ subcutaneously, 3 times daily (TID). During the next few days, the chylous fluid became
Fig. 2. The clavicular head of the sternocleidomastoid muscle $(\mathrm{F})$ is dissected and grasped with a forceps. Dotted line shows the rotation of the flap.

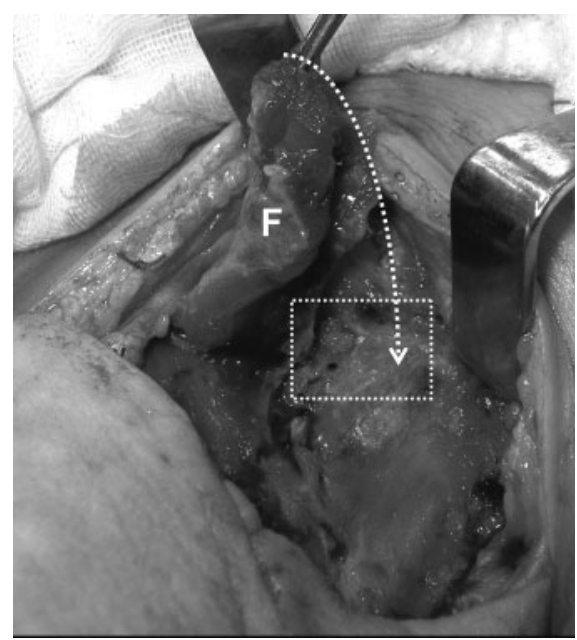

clearer and more runny. However, the fluid flow was still more than 250 $\mathrm{ml}$ per day. Hence, an open surgical repair for fistula was performed under general anesthesia on the 16th postoperative day. The orifice of the fistula was observed on the posteromedial side of the clavicle on an edematous and pale surgical base. The clavicular head of the sternocleidomastoid muscle flap was dissected and rotated over the orifice. Fibrin glue (Tisseel ${ }^{\circledR} /$ Tissucol ${ }^{\circledR}$, Immuno AG, Vienna, Austria) was also applied to the surgical field (fig. 2). Drainage decreased to $10 \mathrm{ml}$ per day in the following 2 days, and the drain was taken out on the 3 rd postoperative day.

\section{Discussion}

The supraclavicular nodal basin lies outside of the primary lymphatic drainage pathways of the breast. Hence, contralateral supraclavicular recurrence is staged as $\mathrm{pN} 3 \mathrm{c}$ and is considered as distant metastases for breast cancer. Especially contralateral supraclavicular lymph node metastasis without axillary recurrence is an extremely rare condition. In our opinion, previous axillary and anterior neck dissections and total thyroidectomy operations might result in distortion of lymphatic pathways and small collateral lymphatics may get activated. However, we could not show any distorted pathways of lymphatic vessels due to the patient's refusal of further imaging studies. Our lymphatic pathway distortion hypothesis may also explain the uncommon, right-sided CF that complicated the neck dissection. Although the anatomy of the thoracic duct is well known, CF after neck dissection occurs usually on left side. De Gier et al. [2] reported 11 chyle fistulas in 139 left neck dissections, and only 1 chyle fistula in 132 right neck dissections. Nussenbaum et al. [4] elicited 13 left- and 2 right-sided chyle fistulas after 635 neck dissections. Mastectomy has also been reported as a cause of chyle fistula. Nakajima et. al. [5] reported 4 left-sided chyle fistula after mastectomy operations of 851 breast cancer patients.

An increase in the drainage volume in the early postoperative days and white-gray, turbid fluid are an indication of fistula [4, 6]. Biochemical analysis of the fluid may confirm the diagno- 
sis. Rogers et al. [7] concluded that a drainage fluid triglyceride level above $100 \mathrm{mg} / \mathrm{dl}$ or greater than the serum level would support the $\mathrm{CF}$ diagnosis. T lymphocytes predominating the leukocyte count between 400 and 6,800 cells $/ \mathrm{mm}^{3}$ is also a diagnostic indicator. The results of the biochemical analysis of the drained fluid of the presented case were harmonious with the literature.

Treatment modalities of CF are still a source of debate due to their rare occurrence. Immediate surgical repair seems to be the best choice when chylous leakage is observed during the operation [4]. Closed-wound drainage, pressure dressing, and dietary modifications were cited as successful conservative treatment options for low output fistulas [1-3]. Dietary modifications include delaying enteral feeding or use of a mediumchain triglyceride (MCT) diet. Total parenteral nutrition may be an initial treatment option, or may serve as an alternative nutrition method for patients in whom the MCT diet could not reach a prompt response $[2,4,6]$. Sclerotherapy with tetracycline was used as accompanying treatment to conservative management $[8,9]$. Treatments of $\mathrm{CF}$ with somatostatin analogues were advocated in several articles [10-11]. The dosage and route of administration of octreotide seems to be variable in the literature. Valentine et al. [10] began therapy with 0.05 $\mathrm{mg}$ intravenously TID; afterwards he modified it to $0.1 \mathrm{mg}$ subcutaneously TID due to low response after the initial dosage. Nyquist et al. [11] administrated octreotide $100 \mu \mathrm{g}$ subcutaneously TID. Markham et al. [12] attempted octreotide therapy with $3 \mu \mathrm{g} / \mathrm{kg}$ subcutaneously TID in a canine model. Nyquist et al. [11] and Markham et al. [12] revealed that drainage ceased on the 8 th and 16th day, respectively. We administered octreotide $0.1 \mathrm{mg}$ subcutaneously TID. Contrary to the literature, drainage persisted for 14 days with no change in volume, although the daily output was less than $500 \mathrm{ml}$.

Even though there is no consensus on indications and timing, surgical repair is recommended for fistulas exceeding $500 \mathrm{ml}$ drainage per day, and in the case of any complication due to leakage $[2,4]$. Once drainage continued to the 16th postoperative day, we decided to perform surgical repair to allow the patient to undergo further oncological treatment as soon as possible. Different surgical techniques such as pectoralis major myocutan flap, sternocleidomastoid muscle flap, clavicular periosteal flap, and free fat graft have been published for treatment and reconstruction of CF $[2,4,13,14]$. We preferred the sternocleidomastoid muscle flap technique because of convenient location and easy handling. Furthermore, approaching CF via a previous incision resulted in less scar tissue formation.

\section{References}

1 Crumley RL, Smith JD: Postoperative chylous fistula prevention and management. Laryngoscope 1976;86:804-813.

2 De Gier HH, Balm HJ, Bruning PF, Gregor RT, Hilgers FJ: Systematic approach to the treatment of chylous leakage after neck dissection. Head Neck 1996;18:347-351.

$>$ Lucente FE, Diktaban T, Lawson W, Biller HF: Chyle fistula management. Otolaryngol Head Neck Surg 1981;89:575-578.

4 Nussenbaum B, Liu JH, Sinard RJ: Systematic management of chyle fistula: the Southwestern experience and review of the literature. Otolaryngol Head Neck Surg 2000;122:31-38.

5 Nakajima E, Iwata H, Iwase T, Murai H, Mizutani H, Miura S, Kato H: Four cases of chylous fistula after breast cancer resection. Breast Cancer Res Treat 2004;83:11-14.
6 Gregor RT: Management of chyle fistulization in association with neck dissection. Otolaryngol Head Neck Surg 2000;122:434-439.

7 Rodgers GK, Johnson JT, Petruzelli GJ, Warty VS, Wagner RL: Lipid and volume analysis of neck drainage in patients undergoing neck dissection. Am J Otolaryngol 1992;13:306-309.

8 Kassel RN, Havas TE, Gullane PJ: The use of topical tetracycline in the management of persistent chylous fistulae. J Otolaryngol 1987;16:174-178.

9 Metson R, Alessi D, Calcaterra TC: Tetracycline sclerotherapy for chylous fistula following neck dissection. Arch Otolaryngol Head Neck Surg 1986; 112:651-653.

10 Valentine JN, Baressi R, Prinz RA: Somatostatin analog treatment of a cervical thoracic duct fistula. Head Neck 2002;24:810-813.
1 Nyquist GG, Hagr A, Sobol SE, Hier MP, Black MJ: Octreotide in the medical management of chyle fistula. Otolaryngol Head Neck Surg 2003;128: 910-911.

12 Markham KM, Glover JL, Welsh RJ, Lucas RJ, Bendick PJ: Octreotide in the treatment of thoracic duct injuries. Am Surg 2000;66:1165-1167.

13 Yoshimura Y, Kondoh T: Treatment of chylous fistula with fibrin glue and clavicular periosteal flap. Br J Oral Maxillofac Surg 2002;40:138-139.

14 Casler JD, Brietzke SE: Repair of a high-output chylous fistula with a free fat graft. Laryngoscope 1998;108:938-940. 